\title{
鋼の水素吸收,脆化および破壊（その 1$)^{*}$
}

\section{まえがき}

本報告は NACE，T-1 G 委員会後援のもとに INCO その他 20 社の基金により Yale 大学で著者らによって 行なわ机た実験成績の概要を述べたものである。この試 験の目的は $\mathrm{H}_{2} \mathrm{~S}$ による鋼の応力腐食龟裂の基本的な金 属学的諸因子を探究し腐食亀裂現象の機構を明らかにし て, 将来他の人々が本問題の実際的解決を図るための研 究基礎となすにある。本交の記述，意見，結論等は著者 等自身のものであって必ずしも NACE あるいは T-1 G 委員会のものではない。本交の研究結果を $\mathrm{H}_{2} \mathrm{~S}$ を含む 腐食性液中の実際的諸問題に適用する場合には十分留意 を要する。

\section{序文}

$\mathrm{H}_{2} \mathrm{~S}$ を含む腐食性液中で鋼が瞬間的破壊を生ずること

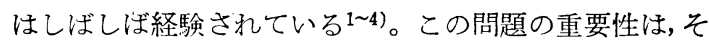
の発生数にはなく，その発生による経済的および技術的 損害の額にある。高圧井戸ケーシングや管のただ 1 個所 の故障によって㽷井となることもある。不測の材料の事 故によって，米国やカナダに拈ける油田の発展が著しく 阻害されている。この問題の重要性は早くから認識され 関倸会社や NACE の TP-1 G 委員会で大規模の実験室 試験および現地試験が施行された。これらの試験の概要 は 1952 年 ${ }^{5)}$ に発表された。この討論会で提議された問 題の複雄性および各種の破壊機構はな抢広範な試験を要 することを明らかにしている。有効な防禦方法を講ずる には破壊機满を十分に理解しなくてはならないし，試験 方法を企画する上からも破壊機構に対する詳細な知識が 必要である。ゆえに TP-1 G 委員会は $\mathrm{H}_{2} \mathrm{~S}$ 中における 鋼破壊機構を研究する目的で Yale 大学金属学部で研究 を開始するように取計った。この報告は 1951〜1955 年 の間 Yale 大学で行なわれた実験結果技よび結論につい て述べたものである。この研究が行なわれる以前から応 力腐食笔裂の原因について多数の仮説が発表されてい る。試験を適切に実施するためまずこ机らの仮説につい て考察を加えて見よう。

\section{1. 考察を加えた仮説}

“硫化物腐食亀裂”なる言葉は腐食の根本原因の不確 実さ定反映している。破壊が腐食性液から吸収された水 素によるものかあるいは金属の腐食とこれに基づいた応

* 訳者：福谷英二 中川防蝕工業(株)

* Bridgeport Brass Co.

*** Hammond Metallurgical Laboratory, Yale Univ. (原交) Hydrogen Absorption, Embrittlement and Fracture of Steel. Corrosion, Vol. 13, No. 7, $437 \mathrm{t} \sim 458 \mathrm{t}$ (1957) July

\section{A. E. Schuetz** \& W. D. Robertson***}

力腐食亀裂によるものかについての意見が一致していな いためにこの言葉が選ばれたのである。この両者の影響 をはっきり区別することは困難である。しかし防止対策 を決める上には決定的な結論を出す必要がある。防止方 法はこれらの二つの場合に全く異なるからである。ゆえ にこの試験の目的の一つは破壊の主因が水素の影響か応 力腐食龟裂かを判別するにある。破壊は多く合金鋼に起 るので，種々の仮説は破壊の原因は金属学的組織にある ものとして立てられた。すなわち（1）マルテンサイト 鋼目が破壊の起点となる。（2）負荷応力のため残留オー ステナイトの変態を生ずることが破壊の原因である等で ある。第一の提案恬詳細な顕微鏡写真による観察と, 焼 純しないマルテンサイトを除去するように熱処理を行な えば破壞を生じ難くなる明らかな事実に基づいている。 残留オーステナイトの変態による機構は, オーステナイ トの $1 \mathrm{~atm}$ における水素溶解度は同温度におけるフェ ライトより大であるから，オーステナイトがフェライト に変態したとき高圧水素を発生し龟裂を生じさせるとし ている。両者ともいくぶん理論および実験に基づいた提 案であるが，いずれも必要にして十分な条件であるか否 かは今後の実験をまたなけ机ばならない。

\section{2. 限界機械的性質}

破損が機械的性質に左右されることはしばしば観察さ れている。ロックウェル C 20 以下の硬度で破壊が起る ことはほとえどない。ごく最近ではこの硬度限度はC 25 に上げられている。この結論は定変形試験結果から導び かれたもので，これらは機械的性質と試験片形状によっ て影響を受ける。一般に用いられる薄いビーム状の試験 片では，中心線では応力が 0 となるから弛緩現象によっ て内部応力の減少が起る。ゆえに低張力鋼の屈曲試験で 破壞が起らなかったとしても，定抗張力を全断面に受け るような試験で破壞が起らないとは言光ない。合金鋼の 亀裂敏感性について結論を出せるような資料は少ない。 定変形試験状態で汇諸性質と応力の関係を明らかにする ことができないのも資料のそしい一因であるが，とにか く系統的な合金成分に関する研究はまだ行なわ机ていな い。石油産業に用いられている市販材料について広範な 試験が施行された結果，オーステナイト鋼やニッケル基 合金は重裂には免疫性であることが証明され，また高 $\mathrm{Ni}$ 鋼は亀裂敏感度が非常に高いし，一般に広く用いられて いる低合金管用材料も応力と化学的環境によっては多分 机少なかれ腐食亀裂に敏感であることが証明されてい る。他の僅少成分についてはあるものは若干有利なもの ああるが余り明らかでない。前述の討論会の研究成果に 
よれば龟裂を促進する主因は $\mathrm{H}_{2} \mathrm{~S}$ であることに疑念汇 ない。Bastien と Amiot") は水のないときあるいは心゙ ンゼンのようにイオン化しない液中では脆性は起らない ことを示している。Fraser と Tresedar ${ }^{5)}$ は水溶液に 酢酸を添加するときあるいは温度を $25^{\circ} \mathrm{C}$ から $0^{\circ} \mathrm{C}$ に 下げるときは亀裂敏感性を増すことを述べている。

\section{3. 未決定の基本的衰愐}

この試験を始めたとき“硫化物腐食俺裂” は応力腐食 亀裂であるか水素脆性であるかの基本的決定はなされて いなかった。 $\mathrm{H}_{2} \mathrm{~S}$ 中で破壊を生じ易い合金はほとえど全 部が十分な応力を加えるかあるい冷間加工した状態の 下で陰極通電によって水素を供給すれば瞬間的に破壊す ることが実験で示されている。最大応力部をビニル塗装 して腐食液につけたビーム状試験片5)では塗装してない 低応力部で破壊が生じた。この実験は水素濃度は均一で あると仮定して腐食過程が破壊の原因であると解釈され た。ある試験では郝性ソーダ液中で陰極的に水素を発生 させても破壊を生じなかったが，このことは水素だけで は硫化物環境中で瞬間的破壊を引起すに十分でないと解 勫されている。

\section{4. 腐食吾裂の锶察}

腐食亀裂の存在は彷来観察されている。特に亀裂は局 部腐食による食孔に端を発していることがしばしば観察 されている。しかし Fraser と Tresedar によって硫 化物環境にお沙破壊は一つの大きな重裂であるが，同 じ金属の青化塩液中における重裂は沢山の小龟裂である ことも観測されている。ゆえに硫化物環境中における龟 裂はある程度一般の腐食亀裂とは区別できるように思わ れる。

\section{研究計 画}

$\mathrm{H}_{2} \mathrm{~S}$ 亀裂に及ぼす種々の要因を分離してその影響 程 度を知るため最も簡単な合金を試験に用いることとし た。使用した合金は Ni 0 30\% の合金鋼および炭素量 を種々に变えた炭素鋼である。 $\mathrm{Ni}$ 合金鋼では 2 成分だ

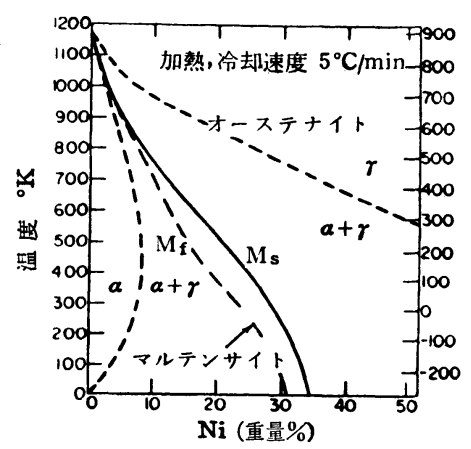

第 1 図 $\mathrm{Fe}-\mathrm{Ni}$ 状態図(Owen と Liu'11) ただし低温部 Kaufman と Cohen $_{8}$ )
けで鉄の三相を 全部得られる。

第 1 図は最近 の $\mathrm{Fe}-\mathrm{Ni}$ 平衡 ○図7)を示したも 进のである。同図 中 $\mathrm{M}_{\mathrm{s}}$ はマルテ ンサイト変態の 起る温度で, $\mathrm{M}_{\mathrm{f}}$ 泠却の際 マルテンサイト 変態の終る温度 である。この変
態点は Kaufman と Cohen ${ }^{8)}$ の研究によって得られた ものである。 $10 \% \mathrm{Ni}$ 鋼を $\gamma-\alpha / \gamma$ 变態点から徐彾すれ 壮体心立方のフェライトを生ずる。同じ温度から急冷す れ泣同じ組成のマルテンサイトができる。 $30 \% \mathrm{Ni}$ 鋼は 常温で面心立方のオーステナイトになるが, 液体空気で $-190^{\circ} \mathrm{C}$ に冷却すればオーステナイトの $95 \%$ 注マルテ ンサイトに変る。どちらの合金もこのようにマルテンサ イトをまじえた三相が全部常温で得られる。ゆえにこの 系統の合金は各種の組織および組成と破壊の関係を調査 するのに好都合である。 $\mathrm{iH}_{2} \mathrm{~S}$ の脆性を起す媒体として の程度を知るため, $\mathrm{H}_{2} \mathrm{~S}$ 中における脆化度と硫酸液中で 陰極通電した場合の脆化度とを比較した。脆化度の調査 は次の 3 性質について行なった。(1) 屈曲試験で鞋性の 变化を計測する。（2）鉄の降伏点に及ぼす水素の影響 （3）靶性の時間による回復。勒性の回復度は特に水素脆 性と腐食俥裂を区別する方法として役立つと考えられて いる。腐食亀裂で破壊された組織は回復することはない からである。事実これは両者を区別する数少ない方法の 中の一つである。

\section{1. 多数の破壊試験の必要}

組織および組成の諸因子の重要度を決定するには多数 の試験が必要である。実験項目を細分すれば次のように なる。

第 1 部 脆性打よび重裂現象

（1） $\mathrm{H}_{2} \mathrm{~S}$ 脆性と陰極通電脆性との比較

（2）定変形試験での合金組成，熱処理，粘性変形お よび化学的環境等の瞬間的破壊に及ぼす影響

第 2 部 $\mathrm{Fe}-\mathrm{Ni}$ 合金の水素吸収

（1） $\mathrm{Fe}-\mathrm{Ni}$ 合金の $\mathrm{H}_{2} \mathrm{~S}$ 液中における水素吸収量と 時間, 合金組成, 組織との関係

（2）硫酸液中での陰極通電による水素吸収量と合金 組成, 組織および水素発生過程に対する化学的諸因子の 関係

第 3 部 $\mathrm{Fe}-\mathrm{Ni}$ 合金のマルテンサイト，オーステナイ ト,フェライト各組織中の水素滲透率

第 4 部 $\mathrm{Fe}-\mathrm{Ni}$ 合金の破壊時間

（1） $\mathrm{Fe}-\mathrm{Ni}$ 合金の静的破壊時間と負荷応力，組織お よび水菜濃度の関係

（2）破壊過程に関する一般的結論

\section{実験方法}

ここでは全般の実験に共通な実験方法についてのみ記 述し，個々の場合に適用される特殊の方法について法そ のつど述ベることとする。

\section{1. 材料}

2 種類の材料を用いた。これら材料の組成を第 1 表に 示す。 $\mathrm{A}, \mathrm{AA}, \mathrm{K}, \mathrm{L}$ の 4 合金は炭素含有量と各種の 熱処理による組織の影響を調查するためのもので， $\mathrm{B}$, 
第 1 表 合金組成

\begin{tabular}{c|r|l|l|l|l|r|r}
\hline \hline 記 号 & \multicolumn{1}{|c|}{$\mathrm{Ni}$} & $\mathrm{C}$ & $\mathrm{Mn}$ & $\mathrm{Si}$ & $\mathrm{S}$ & $\mathrm{P}$ & $\mathrm{Ti}$ \\
\hline A & - & 0.023 & 0.09 & 0.014 & 0.033 & $\mathbf{0 . 0 1 3}$ & $\ldots$ \\
AA & - & 0.04 & 0.09 & 0.10 & 0.029 & 0.015 & $\ldots$ \\
K & - & 0.25 & 0.22 & 0.17 & - & - & $\ldots$ \\
L & - & 0.27 & 0.20 & 0.17 & - & - & $\ldots$ \\
B & 4.89 & 0.04 & 0.15 & 0.03 & - & 0.007 & $\ldots$ \\
E & 10.30 & 0.08 & 0.07 & 0.11 & 0.01 & 0.004 & $\ldots$ \\
G & 30.70 & 0.06 & 0.13 & 0.05 & 0.005 & 0.002 & $\ldots$ \\
N & 10.16 & 0.05 & 0.24 & 0.14 & - & - & 0.44 \\
\hline
\end{tabular}

組成峙重星\%

$\mathrm{E}, \mathrm{G}$ の 3 合金は $\mathrm{Ni}$ 含量と各種の結晶学的構造の影響 を調査するために用いられた。 $\mathrm{N}$ 合金は Ti の影響を調 査するためと, $\mathrm{Ti}$ により僅少の炭素, 酸素, 窒素を除 去する目的で用いられた。定応力破壊試験に用いられた もの以外の全材料は厚さ 0.0625 in の冷間圧延板であ る。

A材は市販の低炭素磁性鋼でアームュ鉄に相当するの で本報告ではアームュ鉄と呼ぶ。他の材料は全部 INCO 社で準備され，アームコ鉄と電解 $\mathrm{Ni}$ から作製したもの である。

\section{2. 熱姏理}

特㲅する場合のほか全合全は垂直型石英管炉に $700^{\circ} \mathrm{C}$ に熱した Ti の上を通して清浄にしたアルゴンを満した 中で熱処理された。要求される 組織に応じて炉中泠却 によりあるいは水中またはブライン中の急冷により大 気温度まで泠した。Massachusetts 工菜大学の B. L. Averbach 教授にたのえで $10 \%, 30 \% \mathrm{Ni}$ 鋼の $\mathrm{X}$ 線解 析をしてもらった。これによって $10 \% \mathrm{Ni}$ 鋼は $1,000^{\circ} \mathrm{C}$ から水中に急冷するときは $0.1 \%$ の完全マルテンサイ トになり， $30 \% \mathrm{Ni}$ 鋼は $1,000^{\circ} \mathrm{C}$ から常温に徐冷する とき $\pm 0.3 \%$ の完全オーステナイトになることがわかっ た。

$10 \% \mathrm{Ni}$ 鋼は炉中で徐冷すればフェライトが得られ， $30 \% \mathrm{Ni}$ 鋼では $-190^{\circ} \mathrm{C}$ の液体空気中で変態を生じさ せれば 5〜10\% の残留オーステナイトを含むマルテン サイトが得られる8)。

\section{3. 実験方法}

実験は $4 l$ 入りの容器に常温の飽和 $\mathrm{H}_{2} \mathrm{~S}$ 液を入れこ れに試験片を浸漬して行なった。液中の酸䋕は空素によ って駆逐した。 $\mathrm{H}_{2} \mathrm{~S}$ は蒸留水中に速続的に注入して飽和 させ過剩分法性ソーダに吸収させた。試験片は布入石 炭酸樹脂製の取付具によって容器中に支持した。石炭酸 樹脂注最初少し膨脹するが非常に安定で便利である。同 じ装置で定変形破壊試験を行なった。石炭酸樹脂製取付 具は 4 点荷重によって屈曲応力を調整し得るように設計 されている。長さ 5 in の試験片の第曲度の均一な中央 部 $3 / 5$ の部分で, 3 点ゲージで計った鹳曲度によって 見かけの応力は求められる。 3 点ゲージの 1 尖端には 1/1,000 in 目盛のダイヤルゲージが取付られている。こ の計測装置は第 2 図に示す。陰極通電は $1 l$ ビーカーで
行なった。電源は二 次電池で, 電極は白 金電極である。大低 $4 \%$ 硫酸が電解液と して使用されたが特 別試験では $10 \%$ 苛 性ソーダ液が使用さ れた。水は蒸留水を 使用した。電流密度 は特記する場合のほ

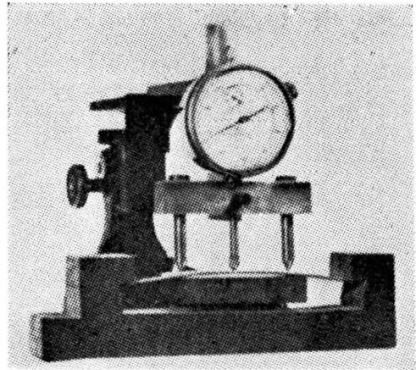

第 2 図 4 点荷重定变形試験装置 か $2 \mathrm{~mA} / \mathrm{in}^{2}\left(3.1 \mathrm{~A} / \mathrm{m}^{2}\right)$ とした。この值は $\mathrm{H}_{2} \mathrm{~S}$ の効果 と陰極通電の効果を比較した絡果選定されたものであ る。

\section{第 1 部 脆性および破壊現象}

\section{1. 屈曲試験による䩖性}

$\mathrm{H}_{2} \mathrm{~S}$ の靱性に及ぼす影響，特に永久腐食傷害の程度を 調查するため，焼鈍したアームコ鉄 A と冷問压延した 軟鋼を， $\mathrm{H}_{2} \mathrm{~S}$ 液中に $0 \sim 140 \mathrm{hr}$ 浸漬した。1/16 in の試 験片を $1 / 2$ in 径のマンドリルを介して繰返し曲げ試験 を行なうのが最も敏感な試験方法であることがわかって いた。破壊するまでの繰返し曲げ回数で鞄性を計測する こととした。この試験方法は驚くほど再現性が良く誤差

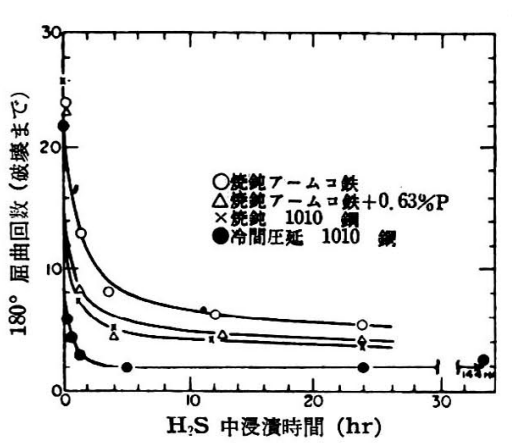

第 3 図 $\mathrm{H}_{2} \mathrm{~S}$ によるアームコ鉄および 軟鋼の勒性変化 以内であっ た。第 3 図に その成績を示 す。図に見る ように鞀性は 急激に降下し て一定値に達 する。曲線の 形状は水素拡 散の特性によ って予想され
は一般に $5 \%$

たものと良く一致している。すなわち水素渗透率は時間 の平方根に比例するが，勒性が水素濃度に反比例するな らば，水素が飽和状態になるまでは鞋性は浸漬時問に反 比例するはずである。

実験結果は常にほぼこの関係を保っている。後に実験 する水素分析から曲線の性質をより詳細に説明し得るで あろう。実験された材料および状態の下では，いかなる 場合にも粒界腐食や組織の時間による腐食破壞の形跡は 認められなかった。靶性変化が組織破壊よりも水素に 関係があることの他の証拠は， $\mathrm{H}_{2} \mathrm{~S}$ 液に浸漬後の時間経 過による勒性の回復である。アームコ鉄を $1,4,24 \mathrm{hr}$ $\mathrm{H}_{2} \mathrm{~S}$ 液に浸漬したものを常温空中に 70 day まで放置し た場合と，同じように $\mathrm{H}_{2} \mathrm{~S}$ 液に浸漬した後沸騰蒸留水 


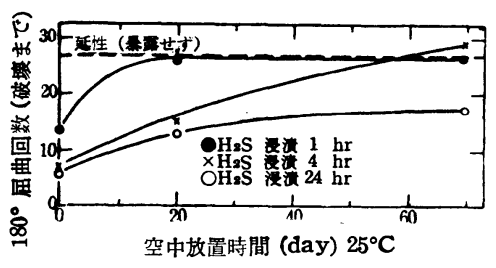

第 4 図 アームコ鉄の空中におけ る鞓性回復状況

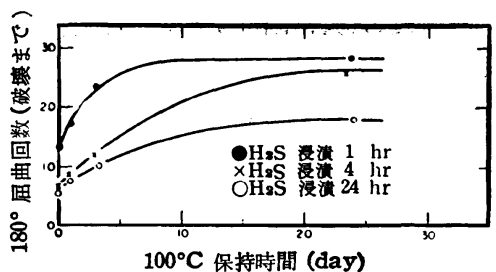

第 5 図 アームコ鉄の $100^{\circ} \mathrm{C}$ 保 持による靶性回復状況
中に $1,3,24 \mathrm{hr}$ 浸漬した場合の 靶性試験を行な った。その成績 を第 4,5 図に 示す。常温にお ける靭性の回 復は明らかに $\mathrm{H}_{2} \mathrm{~S}$ 液浸漬時間 と放置時間に影 響される。 $\mathrm{H}_{2} \mathrm{~S}$ 液に $1 \mathrm{hr}$ 浸漬 したものは 20 day で完全に靫 性が回復し，4 hr 浸漬したも のは 50〜60 day で回復する。 $24 \mathrm{hr}$ 浸漬したものでは 70 day 経過後も完全には回復しない。 $100^{\circ} \mathrm{C}$ におる 䩖性の回復は同様の形態だが若干早い。しかし $100^{\circ} \mathrm{C}$ で処理することは鋼自身の鞄性がその処理によって変る ので問題はやや複雑になる。 $100^{\circ} \mathrm{C}$ に $24 \mathrm{hr}$ 放置すれ ば鋼の鞠性は 26 から 30 に变る。ゆえに $\mathrm{H}_{2} \mathrm{~S}$ 液中に $4 \mathrm{hr}$ 浸漬したものは $100^{\circ} \mathrm{C} に 24 \mathrm{hr}$ 放置しても鞋性が 完全に回復してい ないことになる。 なお放置時間によ る靯性の回復を調 査するため, $\mathrm{H}_{2} \mathrm{~S}$ 液中に $1,4,24 \mathrm{hr}$ 浸漬した試験片を 沸騰蒸留水中に 1，3，24 hr 放置 し, その後 $25^{\circ} \mathrm{C}$ 空気中に 20 day, 70 day 放置して 勒性試験をした成 績を第 6 図に示 す。この試験成績 中 70 day 放置し たときの鞋性回復 状沿を $100^{\circ} \mathrm{C}$ 保 持時閆に対して図 示したものは第 7 図であって $1 \mathrm{hr}$ 目に最低部があ る。

2. 降伏点現象

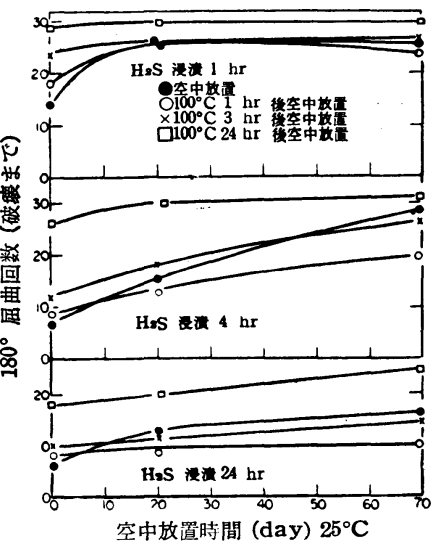

第 6 図 アームコ鉄の空中における 鞄性回復状況

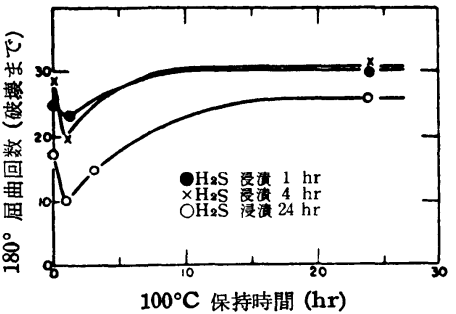

第 7 図 アームコ鉄勒性回復に及ぼ す $100^{\circ} \mathrm{C}$ 保持時間の影響 (70 day 空中放置前の)
前項で述べた試験によって $\mathrm{H}_{2} \mathrm{~S}$ 液中で吸収された水 素の影響がわかる。この現象を更に研究するため $\mathrm{H}_{2} \mathrm{~S}$ 液に浸漬したアームコ鉄 A の疬力一歪曲線と，これを $\mathrm{CS}_{2}$ を含えだ硫酸液中で $2 \mathrm{~mA} / \mathrm{in}^{2}$ の電流を㓌極通電し た場合の応力一歪曲線とを比較した。2 種の試験片を用 いた。すなわち（1） $1 / 2 \times 1 / 16 \times 5$ in の条を圧延方向に 直角に切出したもの，（2）ASTM 標準引張り強さ試験 片を压延方向に平行に切出したものである。引張り強さ 試験は歪の増加率を $0.05 \mathrm{in} / \mathrm{min}$ として行なった。試
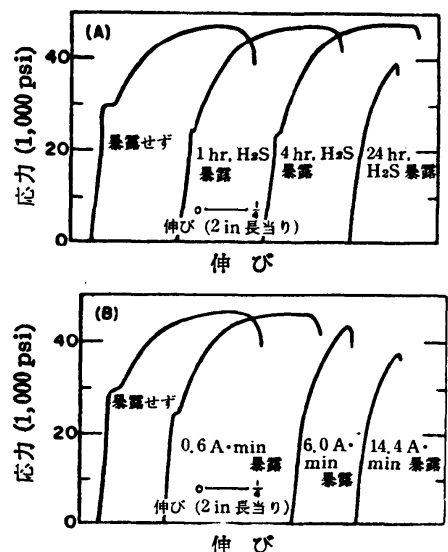

第 8 図 $\mathrm{H}_{2} \mathrm{~S}$ 浸漬と $2 \mathrm{~mA} / \mathrm{in}^{2}$ 㓌極 通電の焼鈍アームコ鉄の降伏点に 及ぼす影響
験は室温で次の二 状態の下で行なっ た。(1) $\mathrm{H}_{2} \mathrm{~S}$ 液浸 漬後空中で15〜60 $\min$ の間に行な う。(2) 飽和 $\mathrm{H}_{2} \mathrm{~S}$ 液中で行なう。 $\mathrm{H}_{2} \mathrm{~S}$ 液中に 1,4 , $24 \mathrm{hr}$ 浸漬した成 績と硫酸液中で陰 極通電した成績を 第 8 図に示す。両 場合とも降伏点に おける応力も伸び も次第に低下す る。降伏点の応力，伸びの漸次低下する状況は鋼板を “調質圧延”する場合のように粘性変形を増すときの状 況と良く似ている。降伏点低下に対する水素の役割を調 ベるため, $\mathrm{H}_{2} \mathrm{~S}$ 液 や陰極通電液に浸 漬後 70 day 室温 に放置して回復さ せた試験片で同様 の試験を行なっ た。その成績を第 9 図に示す。屈曲 試験の場合と同様 に $1 \mathrm{hr}$ 浸漬のも のは弾性限は完全 に回復するが他の 浸漬時間の場合に は完全には回復し ない。浸漬後空中

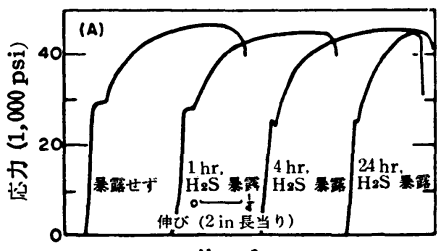

伸 び

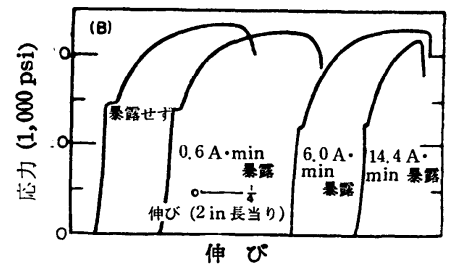

第9図 $\mathrm{H}_{2} \mathrm{~S}$ 浸漬または陰極通電後 70day 空中放置の焼鈍アーム 鉄 降伏点に及ぼす影響
で試験するをでの経過時間の影響を調べるため, $\mathrm{H}_{2} \mathrm{~S}$ 液 中に $1,24 \mathrm{hr}$ 浸漬し, 浸漬したまま引張り強さ試験をし たものと，液から取出後数分空中に放置して試験した結 果を第 10 図に示した。この試験では圧延方向に平行な 試験片を用いたが降伏点が顕著に現われる。液外で試験 


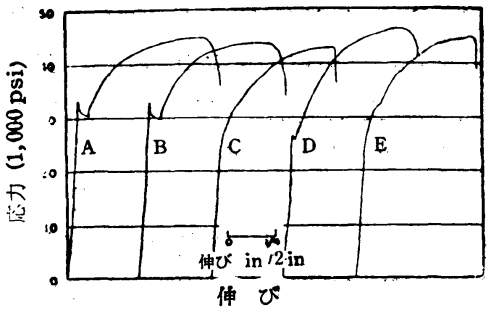

A: 暴露せず

B: $1 \mathrm{hr} \mathrm{H_{2 }}$ S 液外試験

E: $24 \mathrm{hr} \mathrm{H}_{2} \mathrm{~S}$ 液外試験

第 10 图 $\mathrm{H}_{2} \mathrm{~S}$ 液中㧍上び夜外試験時 の焼鈍アームコ鉄の応力一歪曲線
C: 1 hr $\mathrm{H}_{2} \mathrm{~S}$ 液内試験

するときは降 伏点涂り変 らないが液中 で試験すると き海降伏点柾 は完全に現わ 机なくなる。 $24 \mathrm{hr}$ 浸漬の とき液外試験 では小さな降 伏点歪がある が液中試験で はこれがなく粘性正は若干不連続となる。压延方向に平 行な試験片の破断応力の变化は圧延方向に直角な試験片 による場合のものより小さい。この害験の本来の目的に 関しては $\mathrm{H}_{2} \mathrm{~S}$ 液に浸漬した場合も陰極通電の場合も成 績は類似の性質をもっている。現象そのものは水素が鉄 の機械的性質を变える機構に関して非常に興味深い。こ の研究終了後 1952 年に Cracknell とPetch ${ }^{11)}$ が硫酸 中で各種の鋼を陰極通電した同様の試験報告をした。H. C. Rogers 16) も同㥞の実験を行ないさらに降伏点抑圧 に及ぼす温度の影響についても実験を行なった。降伏点 の根本原因は今でも知られていてそれは転位の固着であ る12)。常温では炭素や窒素の転位の束縛力が強くて応力 が弹性限上限になるまでは転位の移動を阻止するに十分 な力をもっている。その後は転位が溶解原子の雲囲気 から引離され下降伏点応力で塑性变形が進行する。 Rogers ${ }^{13)}$ は水素も同様に降伏点に影響するが $-120^{\circ} \mathrm{C}$ 以上の温度ではその影響が現われないここを明らかにし た。ゆえに水素の転位との結合力は炭素より大分弱く， 大体その大きさは水素と炭素とが弾性限との関倸を失な う絶対温度の比すなわち 150:70014) となる。なお第 9 図 に示された降伏点の回復の速さは炭素が塑性変形の後で 拡散によって転位にもどってくる速度より何桁か遅い速 度である15)。それに対して水素の拡散率は炭素のそれよ り数倍早い。ゆえに水素の降伏点に及ぼす影響は, 水素 による炭素原子転位からの变位にのみ帰することはでき ないように思われる。可能性のある説明は鉄中の隙間亦 るいは抗張試験中に生じた隙間に分子状となって入った 水素によって起るかもしれない不均質な忘力によるもの となすべきであろう。このような局部忍力は局部降伏を 生じ，その結果として単一の応力のとき見られる明瞭な 降伏点を消滅させてしまうのであろう。観察された降伏 点現象と脆化および破壊との詳細な関係はまだ良くわか らない。しかしこの実験は水素による機械的影響を研究 する新しい方法を与え，もっと詳細のことがわかってく れば機械的性質に及ぼす悪影響を減ずる方法を見出せる
ようになるかも知れない。

\section{3. 脆化現象の総括}

アームコ鉄に関する限り応力腐食龟裂の現象注見られ なかった。 $\mathrm{H}_{2} \mathrm{~S}$ 液に浸漬の影響は一般に水素吸収による 影響と一致を示した。脆化現象の概要は次の通りであ る。

（1）䩓性の時間による減少は水素の拡散過程と一致 する。

（2）靱性は時間の経過と共に回復する。一定時間内 の回復程度は $\mathrm{H}_{2} \mathrm{~S}$ 液浸漬時間に影響される。

（3） $\mathrm{H}_{2} \mathrm{~S}$ 液に浸漬する場合も硫酸中で陰極通電する 場合も浸漬時間と共に次第に降伏点を低下させる。

(4) $\mathrm{H}_{2} \mathrm{~S}$ 液浸漬後空気中で計った応力一雪曲線は, $\mathrm{H}_{2} \mathrm{~S}$ 液中で計ったものとは鋼から大気圧のもとで水素が 逃出す割合に応じて变化する。

\section{4. $\mathrm{H}_{2} \mathrm{~S}$ 液中における瞬間的破堙}

定变形状態での破壊現象の研究は特定因子の詳細な研 究を行なう前の子備試験である。 $2 \sim 6$ 個の $5 \times 1 / 2 \times$ $1 / 16$ in の条試験片を用い引張応力は $140,000 \mathrm{psi}$ とし た。もっときびしい条件で試験を行なうため，U字形試 験片を $1 / 2$ in 径のマンドリルを介して開口端を閉じる ことによって追加応力をかけ破壊するまでの時間を調査 した。試験の初期に破壊の起るものは大抵 1 日以内に起 り，起らないものは数百時間経過しても起らないことが わかったので， 1 週間経っても破壊しないものはそれで 試験を打切った。

\section{（1）焼入温度}

$\mathrm{Ni}$ 鋼の燒入時間，温度の予備調查を行なった。 $10 \%$ $\mathrm{Ni}$ 鋼 $\mathrm{E}$ の試験片は $1 \mathrm{hr}$ 熱処理し焼入れしてマルテン サイトとした。 $\mathrm{H}_{2} \mathrm{~S}$ 液中における定变形試験の成績を第 2 表に示す。表で見るように焼入温度は破壊作用にほと

第 2 表 $\mathrm{H}_{2} \mathrm{~S}$ 液中の破壊時間 $10 \% \mathrm{Ni}$ マルテンサイト鋼

\begin{tabular}{|c|c|c|c|c|}
\hline \multirow{2}{*}{$\begin{array}{l}\text { 暁 } \\
\text { 温 } \\
\end{array}$} & \multirow{2}{*}{$\begin{array}{r}\text { 入 } \\
\text { 度 }\left({ }^{\circ} \mathrm{C}\right) \\
\end{array}$} & \multirow{2}{*}{${ }^{\text {硬 }} \mathbf{R}_{\mathbf{C}}{ }^{\text {度 }}$} & \multicolumn{2}{|c|}{ 破 壊時間 (hr) } \\
\hline & & & -4 & $\mathrm{U}$ 屈 \\
\hline & $\begin{array}{r}700 \\
850 \\
1,000 \\
1,100 \\
1,200\end{array}$ & $\begin{array}{l}34 \\
35 \\
28 \\
27 \\
24\end{array}$ & $\begin{array}{l}2 \sim 4 \\
3 \sim 5 \\
4 \sim 11 \\
2 \sim 20\end{array}$ & $\begin{array}{c}4 \sim 7 \\
4 \sim 7 \\
2 \\
2 \\
-\end{array}$ \\
\hline
\end{tabular}

えど影響を与えない。ゆえに焼入れは温度 $1,000^{\circ} \mathrm{C}$, 時 間 $1 \mathrm{hr}$ と決めた。

\section{5. 組織，組成と破壊敏感度の関係}

$\mathrm{H}_{2} \mathrm{~S}$ による破壊状況を第 1 表に記載した全材料の組織 および組成について調査し第 3 表に示した。この資料は 機械的性質，組織，破壊敏感度の間に面白い関係がある ことを示している。

\section{（1）機械的性算}

$30 \% \mathrm{Ni}$ オーステナイト鋼 $\mathrm{G}$ と $10 \% \mathrm{Ni}$ フェライト 鋼 $\mathrm{E}$ はどの定変形試験でも破壊しなかった。しかしこ 
第 3 表 $\mathrm{H}_{2} \mathrm{~S}$ 中の亀裂に及ぼす組織と組成の影響

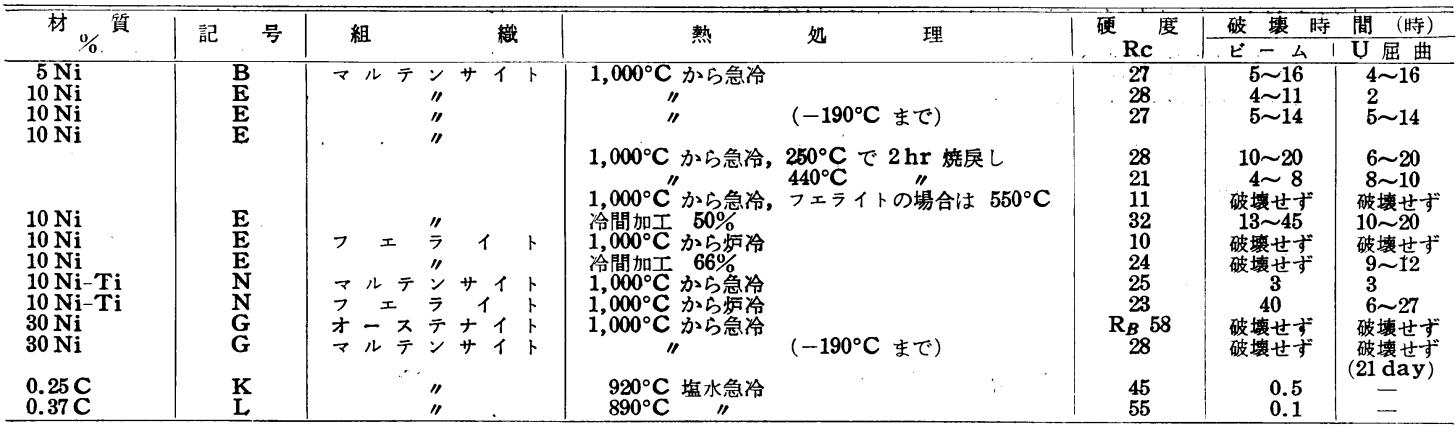

れらの鋼の機械的性質は低く屈曲試験片に貯えられた弾 性エネルギー注比較的小さい。機械的性質の影響を調べ るため $10 \% \mathrm{Ni}$ フェライト鋼を冷間圧延して断面を 60 \% 絞って厚さ $1 / 16$ in の試験片を作った。硬度は口ッ クウエル C 24 となった。この状態で試験片は U 屈曲試 験で破壊した。しかし冷間加工した $10 \% \mathrm{Ni}$ マルテンサ イト鋼は破壊敏感度をいくぶん低下するように見えた。 マルテンサイトを焼鈍すれば予期の通り機械的強度を減 じ十分に焼鈍すれば破壊を生じなくなる。すべての組織 を同じ硬度にすることは不可能であるから同じ機械的性 質の下で直接比較を行なうことはできない。しかし冷間 加工したフェライトが破壊することはフェライトが破壊 に免疫性でないことを示している。10\% Ni 鋼に 0.44\% の Ti を添加すればフェライトの機械的強度を定変形試 験で破壊を生ずる程度まで上げることができ, 第 3 表に 示すように破壊が起る。これらのことはうェライトもマ ルテンサイトも比較し得る状態の下では破壊を生ずるこ とを示している。安定な水素化物を生ずるような因子を 添加する場金は水素吸収による破壊注複雑な栐相を呈す る。

\section{(2) 残留オーステナイト}

$10 \% \mathrm{Ni}$ マルテンサイト鋼の X 線解析の結果 $\pm 0.1 \%$ の精度で残留オーステナイトが存在しないことが証明さ れている。このマルテンサイトはすべての状態で破壊す るから, 残留オーステナイトのマルテンサイトへの变態 が破壊の要件ではない。30\% Ni オーステナイト鋼は破 壊しないが，このことはオーステナイトの変態が破壊を 生ずる問題については決定的事項ではない。しかし他に 根拠がある。 $30 \% \mathrm{Ni}$ 鋼を $-190^{\circ} \mathrm{C}$ でマルテンサイトに 変態させても，いかなる場合にも破壊を生じなかった。 この組織は 5〜10\% の残留オーステナイトを含んでい る。ゆえに残留オーステナイトあるいはそのマルテンサ イトへの変態が $\mathrm{H}_{2} \mathrm{~S}$ 破壊に関係があるとは考えられな w。

\section{（3） 組成}

$5 \sim 10 \% \mathrm{Ni}$ マルテンサイト鋼では $\mathrm{Ni}$ 含量は破壊敏
感度に影響を与えない。しかし $30 \% \mathrm{Ni}$ マルテンサイト 鋼は機械的性質は破壊を生じそうな範囲にあるが破壊を 生じない。後に行なった水素濃度の試験結果は $30 \% \mathrm{Ni}$ 鋼が $\mathrm{H}_{2} \mathrm{~S}$ で破壞しないのは，腐食率が低くて水素含有 濃度が低いことが破壊抵抗の強い原因であることを示し ている。酸素, 炭素, 窒素の影響を種々の方法で調査し た。10\% Ni 鋼 E を湿った水素中で弾性限が現われない 程度まで，また一緒に入れたアームコ鉄の炭素含有量が $0.002 \%$ になるまで脱炭した。その上水素を除くため真 空中で除冷し，アルゴン中で再加熱して後急冷しマルテ ソサイトにした。脱炭したものもしないものもほとんど 差がなくいずれも $2.5 \mathrm{hr}$ で破壊した。0.44\%の Tiを 含む合金 $\mathrm{N}$ は安定な $\mathrm{Ti}$ の炭化物, 酸化物, 窒化物を 作るので, 有効に炭素, 酸素, 窒素を除去するものと期 待されている。しかし第 3 表に示すようにマルテンサイ ト組織のものもフェライト組織のものも $\mathrm{H}_{2} \mathrm{~S}$ 液中で破 壊した。残留 $\mathrm{Ti}$ そのものは破壊の因子ではないので, 不純物は破壞の主原因でないことが結論される。

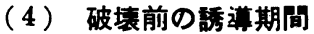

水素が瞬間的破壊の因子であることを証明するため, 水素飽和と不飽和の $10 \% \mathrm{Ni}$ マルテンサイト鋼の破壊時 間の比較を行なった。1 組の 6 個の試験片は応力を加え ないで $\mathrm{H}_{2} \mathrm{~S}$ 液中に $24 \mathrm{hr}$ 浸漬した。後に述べる水素分 析によって試験片中の水素法 $24 \mathrm{hr}$ で飽和することが判 明していた。浸漬後液中で試験したところ平均 $1.9 \mathrm{hr}$ で破壊した。あらかじめ $\mathrm{H}_{2} \mathrm{~S}$ 液に浸漬しない試験片の 破壊所要時間は平均 $4.8 \mathrm{hr}$ であった。この実験の応力 腐食車裂については，応力をかけないで浸漬している間 に生じた侵食によって短時間で破壊を生ずるのだと解釈 したいところである。しかしもっと長い間 $\mathrm{H}_{2} \mathrm{~S}$ 液に浸 漬しても侵食の形跡は認められなかった。逆に水素の飽 和程度に関連する破壊の遅延は水素に関連した破壊の特 性であることが後述の実験で明らかにされる。

\section{(5) 垐装試験片}

Fraser と Tresedar $^{5}$ ) 法水素脆性と応力腐食亀裂機 構を区別するため面白い試験を行なった。屈曲試験片の 
張力側の一部分をビニルで溒装したところ破壊は塗装し ない部分に生じた。張力側全面を塗装したところ破壊は 生じなかった。張力側に塗装しない隙間を残したところ 破壞は直ちにその部で起った。この実験から水素は破壊 の主原因ではないと結論された。彼らは塗装した面も水 素を飽和していて裸部分と同様に脆いのだと考えた。彼 らの試験は破壊機構究明上きわめて重要であるから再実 験，再考察を加えることとした。用いられた 試験片は $10 \% \mathrm{Ni}$ マルテンサイト鋼と $0.37 \% \mathrm{C}$ マルテンサイト 鋼である。塗料はエポキシ，パラフィンおよびゴム基塗 料を用いた。一組の試験片は張力側を全部塗装し，他の 一組はビームの中央と支点との中間を約半分の隙間を残 して張力側を塗装した。10\% Ni マルテンサイト鋼はど ちらの場合も破壊しなかった。炭素マルテンサイト鋼の 場合全面塗装したものは数時間以内に，隙間のあるもの はより短い時間で破壞した。しかし破壤部は隙間部分で なく応力の高い部分であった。この実験の意味は明瞭で ある。水素が試験片の片側から発生するときは非塗装側 から塗装面に向っての水素濃度傾度ができる。破壊敏感 度が高いときは塗装された張力側の水素濃度が破壊に十 分なほど高いのである。破壊敏感度が低いことは必要な 水素濃度に達していないことを意味する。一側を塗装し た試験片の水素濃度の傾度は直線的で, $\mathrm{H}_{2} \mathrm{~S}$ 液に $50 \mathrm{hr}$ 浸瀆した $10 \% \mathrm{Ni}$ マルテンサイト鋼の 4 個の試験片の 平均水素濃度は $1.8 \mathrm{ml} / 100 \mathrm{~g}$ であった。両側を $\mathrm{H}_{2} \mathrm{~S}$ 液に暴露した同じ組成の試験片の水素含有量は平均 3.5 $\mathrm{ml} / 100 \mathrm{~g}$ であった。これらの実験は水素が $\mathrm{H}_{2} \mathrm{~S}$ 亀裂 の主因であることを証明するものである。

\section{(6) 陰拪通電下の破壊}

前項の実験の結果腐食の非常に少ない状態で水素の影 響を調査する必要があることが明らかとなった。このた め $4 \%$ 硫酸中と $10 \%$ 寺性ソーダ中で $\mathrm{CS}_{2}$ のあるときと ないときについて陰極通電試験を行なった。応力は前と
同じように屈曲によって加えられた。第 4 表にその成績 および飽和状態における水素濃度を示した。U 屈曲試験 では塑性変形を生じているので水素含有量は相当増加し ている。これらの条件で瞬間破壊試験を行なった他の人 々の結果は一般に再現性も悪く成績もまちまちである。 しかし一般的傾向ははっきりしている。10\% Ni マルテ ンサイト鋼は硫酸中のU 屈曲試験で例外なく迅速に破 壊している。 $\mathrm{CS}_{2}$ は破壊の必要条件ではない。苛性ソー ダ中に打いてこの材料は破壊しなかった。表に明らか なようにこの液中における吸収水素は $\mathrm{CS}_{2}$ を含んだ硫 酸中のものより少なく, $\mathrm{CS}_{2}$ を含まない硫酸中のものよ りやや少ない。

$30 \% \mathrm{Ni}$ マルテンサイト鋼は $\mathrm{H}_{2} \mathrm{~S}$ 液中では破壊しな かったが陰極通電では例外なく破壊した。後の試験で明 らかなように，この状態に打ける水素飽和量はアームュ 鉄の場合と同様最も多いものの一つで $\mathrm{H}_{2} \mathrm{~S}$ による場合 の約 50 倍である。破壊は水素によるもので腐食反応に よるものでないことを決定的に示すために，苛性ンーダ 中で炭素マルテンサイト鋼に陰極通電しないで屈曲試験 を行なった名全然破壊を生じなかった。しかしこれに陰 極通電すればほとんど即座に破壊した。

\section{(7) 破壊の組桶の路}

Fraser そ Tresedar は $\mathrm{H}_{2} \mathrm{~S}$ 液中における 破壊は単一の大きな亀 裂で，一般の応力腐食 亀裂の場合のような沢 山に分れた小亀裂の性 格のものでないことを 述べている。このこと は本実験でも確認さ れ，顕微鏡検查をして も破壊路を確認し得る

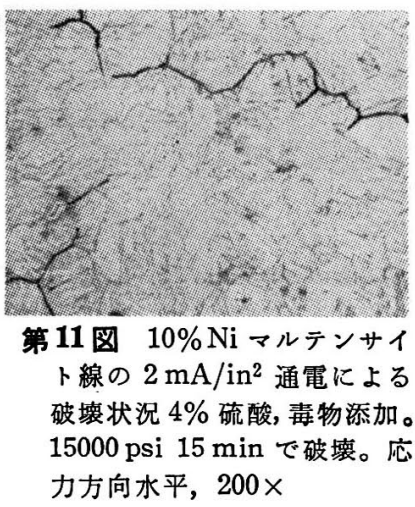

ような付属的小龟裂 を見出せる場合は少 ない。 $10 \% \mathrm{Ni}$ マル テンサイト鋼の陰極 通電による亀裂と $\mathrm{H}_{2} \mathrm{~S}$ 液中に打ける煲 裂状況をそれぞれ第 11, 12 図に示す。破 壊路は才ーステナイ 卜結晶粒界の跡に沿 って起っている。30 $\% \mathrm{Ni}$ マルテンサイ 卜鋼重裂の顕微鏡写 真を第 13 図に示す。 
Vol. 9, No. 1

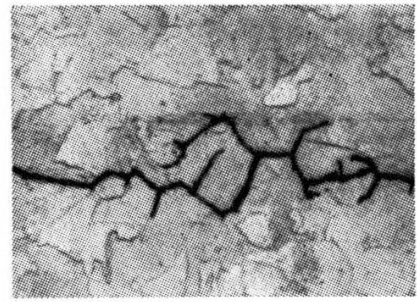

第 12 図 $10 \% \mathrm{Ni}+0.44 \% \mathrm{Ti}$ マル テンサイト鋼の $\mathrm{H}_{2} \mathrm{~S}$ 液中の破壊 状況, U 屈曲試験 $3 \mathrm{hr}$ で破壊. $300 \times$

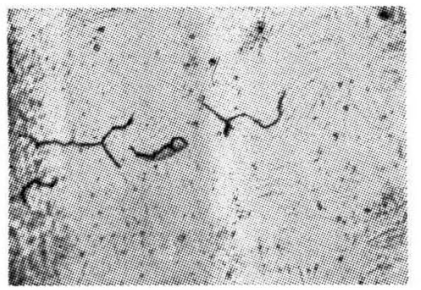

第 13 図 $30 \% \mathrm{Ni}$ マルテンサイト鋼 陰極通電時の破壊状況, 電流密度 $100 \mathrm{~mA} / \mathrm{in}^{2}, 4 \%$ 硫酸 + 物, $\mathrm{U}$ 屈曲 $12 \mathrm{hr}$ で破壊, 応力方向 垂直, $200 \times$

るような顕著な特 徵は見られなかっ た。粒界腐食の敏 感度を調べるため 各種組成, 各種組 織の試験片を応力 をかけないで 35 day $\mathrm{H}_{2} \mathrm{~S}$ 液中に浸 漬した。その後の 組織の顕微鏡検查 では応力腐食龟裂 の敏感性を示すよ うな組織の破壊は 生じていなか。 た。第15図は $\mathrm{H}_{2} \mathrm{~S}$ 液中で一番破壊し 易い $10 \% \mathrm{Ni}$ マル テンサイト鋼の断 面を示したもので ある。試験片はあ

鋼の水素吸収，脆化および破壊（その1）

若干の付属的龟裂 が元のオーステナ イト結晶䊀界に沿 って生じているの が見られる。10\% $\mathrm{Ni}$ フェライト鋼 の静荷重状態にお ける破壊路は第14 図に示すようには っきりしない。こ の試験片は 100 $\mathrm{mA} / \mathrm{in}^{2}$ で陰極通 電し 45,000 psi の 応力で $54 \mathrm{hr}$ 目に 破壊したものであ る。詳細に調查し たところ破壊はフ エライト結晶粒界 に生じていた。沢 山の組織を調査し たが破壊路の性格 をはっきりさせ得

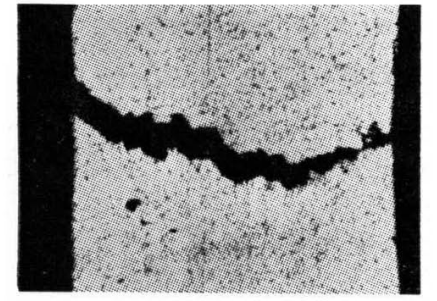

第 14 図 $10 \% \mathrm{Ni}$ フェライト鋼破 壊状況, $100 \mathrm{~mA} / \mathrm{in}^{2}$ 通電 45,000 psi, $54 \mathrm{hr}$ で破壊， $35 \times$

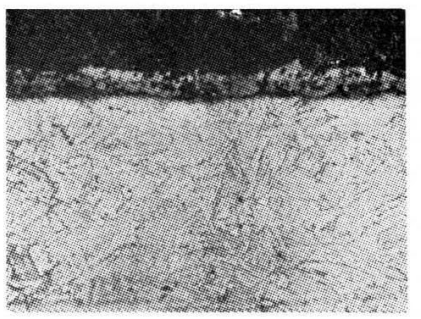

第 15 图 10\% Ni マルテンサイト 鋼 $\mathrm{H}_{2} \mathrm{~S}$ 液に 35 day 浸漬後の状況 （表面に FeS あり） $80 \times$
らかじめ少し曲げて小龟裂の発生があればはっきり出る ようにしてあったが組織は損傷を受けていなかった。こ の検査では他の研究者が見出したような $\mathrm{H}_{2} \mathrm{~S}$ による表 面孔食や孔食に端を発した龟裂を推察し得なかった。孔 食があればもちろんその部から龟裂が起る可能性は高い が，本実験では亀裂の発生は必ずしも孔食を必要条件と しないことを示している。

\section{（8）脆性と破壊現象の總括}

a) $\mathrm{H}_{2} \mathrm{~S}$ 液中に鉄や合金鋼穵浸漬したときに起る脆性 は鉄に吸収された水素の影響である。これは $\mathrm{H}_{2} \mathrm{~S}$ 液から 引上げ後, 時間の経過と共に機械的性質が回復すること によっこ，脆性は水素の吸収によるもので腐食による機 械的性質の变化によるものでないことが明らかである。

b) 陰極通電や $\mathrm{H}_{2} \mathrm{~S}$ による水素吸収によってアーム コ鉄の降伏点降下が起る。この現象も時間経過と共に消 滅するので腐食によるものではない。

c) 顕微鏡検查の絬果は鋼の特別の組織が破填の原因 に関係があるのでもなく破壊路に関係があるのでもない ことを示している。

d) 完全なフェライトまたはマルテンサイト組織では 定変形試験で破壊が起るが，30\% Ni マルテンサイト鋼 で 5 10\% 残留オーステナイトを含むものは $\mathrm{H}_{2} \mathrm{~S}$ 液中 で破壊しない。ゆえにマルテンサイトや残留オーステナ イトは破壞の原因ではない。

e) 酸およびアルカリ溶液中における陰極通電試験の 結果は腐食が破壊の要件でないことを示している。30\% $\mathrm{Ni}$ マルテンサイト鋼が水素吸収の少ない $\mathrm{H}_{2} \mathrm{~S}$ 液中では 破壊せず，水素吸収の多い陰極通電の場合破壊すること は，水素濃度が破壊の原因であることを強く示してい る。

f）実験の結果各水素濃度に対して破壞を生じない応 力の下限があることを示している。

g）微量の酸素, 炭素, 空素等の含有物は破填とは関 係がない。

h) $\mathrm{H}_{2} \mathrm{~S}$ 液に長時間浸漬して組織の破壊が生じなかっ たものでも破壊が起る。明瞭な腐食亀裂の見られないこ とは必ずしも絶対に応力腐食亀裂が亀裂の原因でないと も断定はできないが，他の機構が亀裂の責任者であるこ とを示しているものと考光られる。現在の資料の示す範 囲では $\mathrm{H}_{2} \mathrm{~S}$ 液からの水素の吸収が龟裂の主因と思われ る。

(次号に統く) 